\title{
Study on the English Literature Education in the Respective of International Understanding Education
}

\author{
Li Wei \\ Xi'an International University, Xi'an 710105, China
}

450384173@qq.com

\begin{abstract}
Key Words: International Understanding Education, Foreign Language Education, Traditional English Literature
\end{abstract}

\begin{abstract}
Thanks to the International Understanding Education, multilateral knowledge and understandings of different countries have been enhanced dramatically worldwide, which in a sense guaranteed peaceful coexistence and friendly collaboration among people from various backgrounds. That means we should remain committed to keeping pace with times and breaking through limits in modern English literature education. Only when we are learned of the main-stream development view, can we renovate our ideas to make major contribution for the development of international understanding.
\end{abstract}

\section{International Understanding Education}

Usually, education is a major platform on which knowledge was passed down. As a result, the content and knowledge of international understanding education should be well-acknowledged. At the same time, the Consciousness awakening education, as an integral part of public education, must be held up as a pre-requisite if we are to gain advantages in the global competition in future.

Starting with cultivating the recognition of national cultures among adolescents around the world, international understanding education, as widely believed in global community, offered teenagers deep insights into the latest development in cultural and scientific fields on the planet.

Besides that, students have to pay attention to following aspects:

a .Sound outlook on life and values; b. critical analysis of other countries' political and social situation; c. unbiased understanding of the relationship between competition and cooperation and of the unusual political, economic and cultural relationship between countries; d. right life values of modern college students; e. the unshakable responsibility and obligation for the world.

\section{The background of the birth of International Understanding Education}

Last century is an era of conflicts, among which Word War Iand Word War II have led to severe damages for humankind, leaving tens of millions of people homeless. Even after the Word War II, as the confrontation and conflicts continued to mount worldwide, the international order was greatly spoiled, and it has worsened with the upgrading struggle for hegemony between America and Soviet Union. However, after the cold war, cooperation amid competition and mutual benefit emerged as the topic of the new era. Pushed by the Free Trade Theory, trans-continental and trans-national connections have been increasingly strengthened in economic, political, literary and 
scientific sections. As Globalization concept rose, countries all worked even harder in search of frequent economic interactions and political allies, which was deemed as an important international strategy. But as the exchanges skyrocketed, misunderstanding and even conflicts were difficult to avoid. In this connection, it's necessary for all countries make bigger efforts in the teaching of "we have to respect and understand cultures of other countries", and this is the definition of international understanding education.

Born in the second half of $20^{\text {th }}$ century, the New Technological Revolution has already swept the world. As high-tech talents in $21^{\text {st }}$ century, we have to not only gain new knowledge and develop better innovation ability, but also learn to cooperate amid competition. With the convenient global exchanges led by the rapidly-developed information technology, access to literary and other cultural resources are no longer a tough issue. However, this also brought with itself frictions and collision between domestic and foreign education ideas. But these frictions and collision have also laid the foundation for the international understanding education.

As the globalization remains well under way, it's a prominent job for every country to integrate itself into the global community. As such, when it comes to global issues, none of them can be allowed to shirk from their international responsibility. In face with new historical tasks, countries should enhance their efforts in protecting their national culture other than deepening understanding of international knowledge, global responsibility, international communicative ability, multi-system and diverse cultures. Therefore, we should build an international cultural understanding system to enhance the mutual understanding of educational and scientific aspects in global community.

\section{The Development of English Literature}

Having experienced a long history in its course of development, English literature has made a indelible contribution to the world literature.

The Period of Old English ( $8^{\text {th }}$ to $12^{\text {th }}$ century AD.)

Beowulf is one of the longest and most complete heroic epics in the world. Including two parts and 3,182 lines, this Britain's national epic mainly recorded the heroic deeds of a hero who was called Beowulf in old English. As a dialect epic, Beowulf was written in old English, has a unique set of meter and rhyme. It's also this masterpiece that nobody knows who the author is, open the era of English literature.

Renaissance $\left(14^{\text {th }}\right.$ to $17^{\text {th }}$ century AD.)

Originated in Italy, $14^{\text {th }}$ century, Renaissance soon swept Europe in a short period. Throughout the duration of this remarkable event, superstars of English literature emerged, including famous playwright William Shakespeare and humanism thinker Thomas More, securing an important position for English literature in the international literature.

\section{Since $18^{\text {th }}$ Century}

In $18^{\text {th }}$ century, English prose emerged as a new force in world literature community. The beginning of English prose date back to two famous magazines Tatler and Spectator founded by Joseph Addison and his friend Richard Steel. These two magazines mainly recorded people's 
ordinary life, which was widely favored by people at that time. And this clear, elegant and flexible kind of essays became the predecessor of English prose.

$18^{\text {th }}$ and $19^{\text {th }}$ centuries have witnessed the blowout of talented novelists of Britain, including William Thackeray and Charles Dickens who made great contributions to the development of English literature.

Due to historical issues, English literature has long been a model for English-speaking countries to imitate. However, with the development in both economy and culture of those countries, batches of literature creators with their local characteristics continued to turn up.

Among them, American literature is most successful one who has not only ridded itself of the influence of English literature but also formed their own national features and cultural characteristics. It's worth mentioning that American literature has been long at the forefront of global literature.

Back in colonial period, most of American literature was short of local and national characteristics. Around the independence war, many progressive works kept to spring up. Admittedly, these works were a bit rough, but in these works a unique national cultural style was conceived. In 1930s, literature workers in America launched the Transcendentalism campaign, which was then held up as one of the most significant event in the history of American Thought. At the end of $19^{\text {th }}$ century, deepening social contradiction became a heated debate in America. Realistic writers also turned to these severe issues, slum dwellers and their life became the major part of temporal literature works. Later in $20^{\text {th }}$ century, American literature continued to gain strong momentum and led the trend of world literature in several decades. Also at the time, Imagism Movement swept the world, elements of oriental poetry melted into the creation of American poetry, leaving a deep and profound impact over the development of American poetry. In 1922, T.S Eliot published The Waste Land, a long poem which described the chaotic and corrupt reality of American society from many aspects including humanism, social ethics and citizen consciousness and responsibility. Meanwhile, a good many novelists devoted to the depiction of the cruel social reality, which laid a solid foundation for the later development of literature creation. During the World WarII, many Jewish writers fled to America, which in other words injected new blood into the development of American literature. As the World WarII came to an end, America became one of the two superpowers around the world, with great development in economic and literature sections. And diversity was cherished as the theme of literature, minority writers came out one after another, a literature form represented by Hispanic American literature has been growing continuously.

The creation and consumption of English and American literature were closely connected with Britain's historically dominant political and economic role. But it doesn't mean that all English-speaking countries have to blindly copy English literature. On the contrary, they rapid developed as they created and carried forward with their own features. 7 writers from English-speaking countries were awarded with Nobel Prize in Literature, and more with Booker Prize so far. These writers made remarkable achievements, in their masterpieces, they expressed their love for both their lovers and their motherlands. If we understood their feelings in these works, 
we can get a deeper understanding of their living conditions, which would in turn better settle friction and contradictions in global exchanges. And this coincides with the aim of international understanding education. Therefore, we can concluded that international understanding education has a close relationship with world literature, especially English literature.

In China, after the college entrance examination was resumed in 1977, English literature lessons were set as major access for English major students to get reads on English-speaking countries. Based on English and American literary works, the lesson was designed to develop students’ ability in four aspects, including listening, speaking, reading and writing.

\section{The Relationship Between International Understanding Education and English Literature}

Having received education, students could know others and themselves once when they have known the world. Each one of them should know their own origins, based on which their position in the world were determined. At the mean time, having learned of the cultural differences between their motherlands and foreign countries, they could comprehend some corresponding principles of the international understanding education. For example, if we have learned English, we are able to communicate with people from English-speaking countries, the same is true with literature, if we understand English literature, we are better able to embrace foreign cultures in spite of differences or misunderstandings, and more importantly, the peaceful development of the world would be boosted. Finally, if we are to better understand the protective effect of International Understanding Education for English literature, we have to understand following points:

To give top priority to national culture and better digest and absorb it; b. To recognize the necessity of understanding and respecting other cultures; c. To develop our self-cultivation while studying foreign cultures.

The ultimate goal of the International Understanding Education is to maintain peaceful world. That means all countries should work in bigger effort to develop themselves and ride the current global trend so as to create a higher living standard, a better healthcare system and a more complete education system while keeping centered with cultural development. For literature, International Understanding Education has not only provided it with sound development space and broadcasting conditions but also a vast market for its futuristic development. In the complicated global community, understanding led to peace and unity while wiping out complexity and frictions.

In today's complicated international environment, International Cultural Education takes an important role, meanwhile Foreign Language Education serves as the heart of the International Cultural Education. Currently, educational department once put forward initiatives to cut English's proportion in education, which contradicted my point of view. Since our country is still in the development stage, we are still left behind in cultural, economic and many industries. That means learning from other countries is still a important job for us. Finally, under the protect of international understanding education, foreign language education should be better bolstered as a way to cultivate more qualified talents for the future development.

The International Understanding Education is aiming at cultivating cultural approval for foreign cultures among students, that means English literature is a way of International 
Understanding Education. English literature education was designed to develop students' ability in four aspects, including listening, speaking, reading and writing.

Reading English and American literary works can help students better understand the innovation of these works, cultivate critical thinking and self-criticism ability. English literature education brings to students many benefits, among which the development of their language competence and their own quality is the remarkable one. With English literature, students could master the basic English ability in a short period, which is the foundation underlying their future studies. As a long-existed problem in English literature education, the entanglement of English and American literature has long puzzled educators worldwide. At the beginning of $21^{\text {st }}$ century, educators in China has realized this and many universities launched related research items, they have put forward the idea of widening the range of English literature by bringing the English-speaking countries' literature into it. They also came up with the concept of “English-Speaking Countries’ Literature”.

Starting from scratch, International Understanding Education is now full swing. Many new models of English literature education has replaced the traditional educational methods, and the research of English expressions in English literature have entered into the view of Chinese English literature researchers and students. English literature is a way of International Understanding Education, and the development of International Understanding Education is of great significance for the cultivation of global vision, judge and managing ability of international affairs for students, and for the strengthening of transnational cultural exchanges, information passing and business intercourses. Therefore, English literature education provides International Understanding Education with good conditions. All countries should devote to build related International Understanding Education platforms, on which more local cultural traditions, regional characteristics and historical inheritance of English-speaking countries were better demonstrated and performed.

\section{Conclusion:}

English is spoken by the largest number of people in the world, and it gives students broader global visions. At the same time, classic English literary works, including various kinds of creations and comments, have led to substantial development for English literature. Back in China, English literary works has broadened students' horizons and enhanced their understandings of English education of English-speaking counties. Having received English literature education, students have formed overall and correct world outlooks and life values. And this accords with the idea of peaceful development between cultures in International Understanding Education, stabilize the well-established global position for China, and facilitates the economic, politician, cultural communications between China and all parts of the world.

In conclusion, modern Chinese English literature education is required to keep pace with times and make major breakthroughs. If we are to innovate our thinking and to understand the International Understanding Education, we have to attain truths from more practice. Only when International Understanding Education is rapidly developed, can we finally achieve the worldwide peace. That means all countries should work in bigger effort to develop themselves and ride the 
current global trend so as to create a higher living standard, a better healthcare system and a more complete education system while keeping centered with cultural development.

\section{References:}

[1] Yu Xin. Study on the Development of International Understanding Education[J], Studies in Foreign Education, 2002,8.

[2] Xu Hui, Wang Jing. Study on the International Understanding Education[J], Journal of Southwestern Normal University (Humanity \& Social Science edition), 2003, (6).

[3] Yang Xiuyu. Understanding for Education and Dialogues for Understanding[J], Modern Science of Education, 2006, (2).

[4] UNESCO Chinese Department translated. Education-Where the Treasure Lays[M].Beijing: Science of Education Press,1996.

[5] Liu Haiping, Wang Shouren. A History of American Literature (Chapter 1)[M]. Shanghai: Shanghai Foreign Language Education Press, 2000. 